\title{
Heterotopic Ossification in Hip and Knee Joint After Abdominal Surgery
}

\author{
Abdominal Cerrahi Sonrası Kalça ve Diz Ekleminde Gelişsen \\ Heterotopik Ossifikasyon
}

\author{
Özlem Altındağ, Birsev Küçükoğlu \\ Gaziantep Üniversitesi, Fiziksel Tıp ve Rehabilitasyon Anabilim Dalı, Gaziantep, Turkey
}

\begin{abstract}
Heterotopic ossification is a process characterized by the lamellar bone formation in tissues that do not ossify under normal conditions. Although the etiology is not entirely clear, trauma has been considered as an initiating factor for heterotopic ossification. Heterotopic ossification generally occurs in the hip, knee and shoulder joints. Cases with heterotopic ossification have been reported as a slowly developing complication following trauma, spinal cord lesions, stroke, arthroplasty, and burn injury. In this report, a patient with heterotopic ossification developing 20 days after surgery for ruptured aortic aneurysm is presented and discussed in light of the recent literature.
\end{abstract}

(Turk J Rheumatol 2010; 25: 156-8)

Key words: Heterotopic ossification, aortic aneurysm

Received: 08.07.2008

Accepted: 22.08 .2008

\section{Özet}

Heterotopik ossifikasyon bir eklemi saran yumușak doku içinde lamellar kemik olușumu olarak tanımlanmaktadır. Sebebi tam olarak bilinmemekle birlikte kasta ya da periosteumdaki bir travmaya bağlı olabileceği ileri sürülmüștür. Kalça, diz ve omuz gibi büyük eklemlerde görülebilir. Spinal kord yaralanması, inme, yanık, artroplasti, travma sonrası ortaya çıkan vakalar bildirilmiștir. Bu yazıda aort anevrizma rüptürü nedeniyle opere edilen ve 20 gün sonra heterotopik ossifikasyon gelișen bir kadın hasta bildirildi ve literatür bilgileri ıșığında tartıșıldı.

(Turk J Rheumatol 2010; 25: 156-8)

Anahtar sözcükler: Heterotopik ossifikasyon, aort anevrizması

Alındığı Tarih: 08.07.2008 Kabul Tarihi: 22.08.2008

\section{Introduction}

Heterotopic ossification is a pathological new bone formation occurring in tissues that would not normally ossify. The ectopic bone is located extra-articularly and the joint capsule is intact. It occurs in the connective tissue between muscle layers (1). The etiopathogenesis is not clear yet. However, tissue hypoxia caused by circulatory disorders, abnormal calcium metabolism, loss of control in the sympathetic nervous system, microtraumas connected to range of motion exercises, and genetic factors are suggested (2). When etiological factors are taken into consideration, heterotopic ossification can be handled under the headings of neurogenic or traumatic. Neurogenic heterotopic ossification occurs after head trauma, spinal cord injuries and cerebrovascular events. Traumatic heterotopic ossification occurs after fractures, total hip and knee arthroplasty and direct traumas related to sports injuries. In addition, it may occur during the course of burns, systemic metabolic diseases, connective tissue diseases, and malignancies (3).

Heterotopic ossification usually starts to occur within two weeks after injury and clinical findings present in 8-10 weeks (1). It is seen more frequently in the hip joint, but can also be seen in shoulder joints. The first clinical signs are usually localized swelling, pain and limited movement. Clinical findings, laboratory tests, three-phase bone scintigraphy, ultrasonography, and computed tomography are helpful in the diagnosis. Indomethacin, radiotherapy and bisphosphonates are used in the treatment. After surgery, single-dose radiotherapy and especially indomethacin ( $75 \mathrm{mg} /$ day) are recommended for prophylaxis. Etidronate may inhibit calcium disodium precipitation and osteoid mineralization and may prevent the formation of new bone. The prognosis in patients with early diagnosis and treatment is quite good. Surgical

Address for Correspondence: Dr. Özlem Altındağ, Gaziantep Üniversitesi, Fiziksel Tıp ve Rehabilitasyon Anabilim Dalı, Gaziantep, Turkey Phone: t90 34236060 60/ 76280 E-mail: ozaltindag@yahoo.com 
treatment is rarely needed. In this paper, we report a patient operated due to aortic aneurysm rupture who developed heterotopic ossification in her knee and hip joints.

\section{Case Presentation}

A 52-year-old female patient was admitted to our clinic with pain, swelling and limitation of motion in her left leg. It was learned that the patient underwent aortic valve replacement and aortoiliac bypass approximately 20 days ago. The patient was cooperative. She was brought to the outpatient clinic by stretcher. She described pain in the left thigh and leg, which increased when she tried to move her leg. Swelling was present approximately $5 \mathrm{~cm}$ above the left knee joint. There was no color change or spasticity. Deep tendon reflexes were normoactive. The knee and hip joint range of motion could not be evaluated because of severe pain. Laboratory examinations results were as follows: hemoglobin $(\mathrm{Hb})$ : $10.2 \mathrm{~g} / \mathrm{dl}$, hematocrit (Hct): $32 \%$, white blood cell (WBC): $5200 / \mathrm{mm}^{3}$, platelet: $30,000 / \mathrm{mm}^{3}$, erythrocyte sedimentation rate: $22 \mathrm{~mm} / \mathrm{h}, \mathrm{C}$-reactive protein: 4 , and alkaline phosphatase (ALP): $460 \mathrm{U} / \mathrm{L}$. Other biochemical tests and urine tests were within normal limits. Periarticular osteosis areas were seen around the left hip joint in pelvic radiographs (Figure 1). No new bone formation around the knee joint was seen on the X-ray (Figure 2). In the left hip and knee bone scintigraphy, increased osteoblastic activity was considered as heterotopic ossification developing in two separate regions. The patient was started on passive joint range of motion exercises for the knee and hip joint. Cold pack on the hip and knee joints three times daily for 20 minutes was recommended. Indomethacin (75 mg/day) and etidronate disodium (400 mg/day) were given. Control of pain and decreased swelling were achieved after approximately 20 days, and increase in range of motion was detected. Joint range of motion and stretching exercises were continued with the rehabilitation, and the patient was recommended to continue treatment with etidronate disodium for three months.

\section{Discussion}

In view of heterotopic ossification developing after surgery in patients, this syndrome is thought to occur with long-term immobilization $(4,5)$. However, heterotopic ossification in our patient developed in the early postoperative period, which may suggest the role of abdominal surgery in the etiology. Our patient had sudden severe abdominal pain, back pain and syncope and was operated in a special emergency center. During the operation, a ruptured abdominal aortic aneurysm due to aortic segment aneurysm was detected, and exploration, graft and iliac artery anastomosis were done.
A few heterotopic ossification cases developing after abdominal surgery have been reported in the literature $(6,7)$. Our patient admitted to our hospital approximately 20 days after the operation. However, her complaints began earlier. In addition, calcification around the hip joint, which could be seen on the direct radiograph, showed that the bone maturation (heterotrophic ossification) started earlier. Jacobs et al. (7) reported a case of heterotopic ossification in multiple joints occurring after necrotizing pancreatitis operation. They suggested that this heterotopic ossification may be related to abdominal surgery and not a result of delayed rehabilitation like in spinal cord injuries or traumatic brain injury.

In surgical treatment of aneurysm rupture, the aorta is clamped during the anastomoses and temporarily obstructs the circulation of the extremities, leading to circulatory disorders (8). In the present case, the circulatory

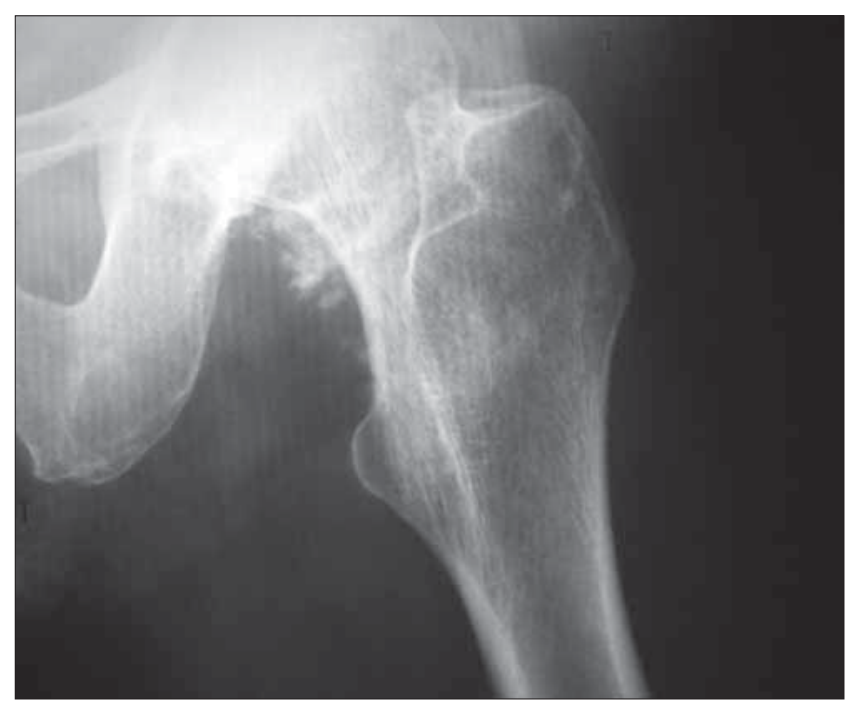

Figure 1. Periarticular osteosis around the hip joint in pelvic radiographs

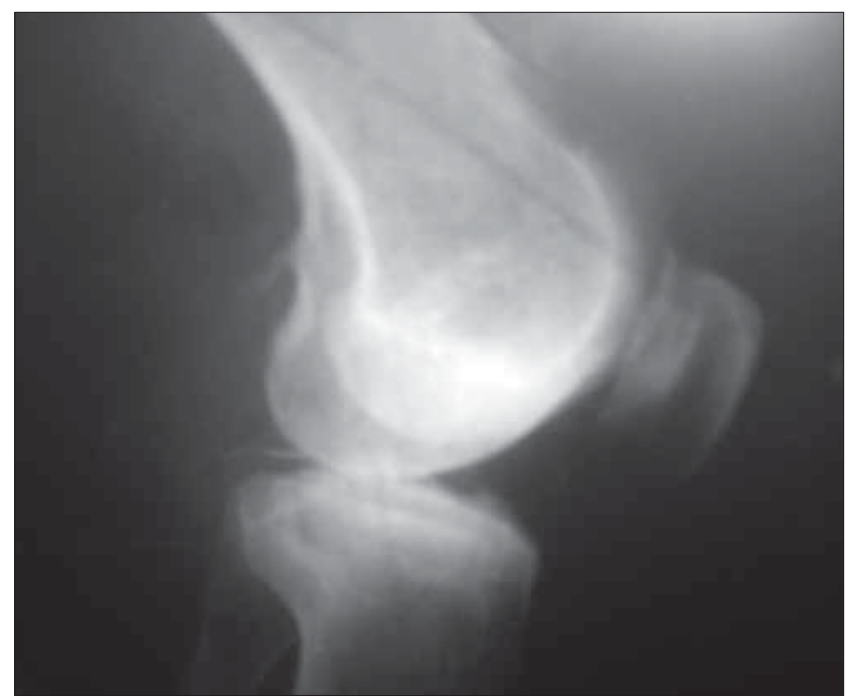

Figure 2. No new bone formation around the knee joint on the X-ray 
problems that occurred during the anastomosis may be a risk factor for the heterotopic ossification. Heterotopic ossification emerging after abdominal aortic aneurysm was reported in a female patient aged 55 (7). In this case, heterotopic ossification around the hip joint recovered after six weeks nonsteroidal anti-inflammatory drug treatment.

It has been reported that heterotopic ossification developing in six patients with adult respiratory distress syndrome may be related to neuromuscular blockade (9).

Another characteristic that separates our patient from other cases was the location of heterotopic ossification, which was seen in the knee and hip joints. Imaging results show that heterotopic ossification developed in the hip and then in the knee joints.

Heterotopic ossification may occur in different regions and very rarely away from the joints. Endometrial ossification after abdominal surgery, rectal ossification due to adenocarcinoma, cutaneous ossification due to mixed connective tissue disease, and pulmonary ossification due to diabetes were reported (10-13).

The etiopathogenesis of heterotopic ossification has not been fully explained. However, it has been suggested that tissue hypoxia due to trauma and immobility, an inflammatory reaction and new bone tissue formation due to circulatory slow down may explain its development. The emergence of heterotopic ossification in different clinical conditions may suggest an underlying genetic predisposition. In recent years, bone morphogenic protein was suggested as a new factor that may cause new bone formation.

Although heterotopic ossification has various etiological factors, treatment usually consists of range of motion exercises, nonsteroidal anti-inflammatory drugs, bisphosphonates, radiotherapy, and surgical treatment options. In the present case, it is difficult to determine the possible cause of the heterotopic ossification. It may have been due to the abdominal surgery, immobilization or circulatory disorder. However, it should be kept in mind that early diagnosis and radiological and laboratory followup are very important for all of these clinical conditions.

\section{Conflict of Interest}

No conflict of interest is declared by authors.

\section{References}

1. Yanık B, Yalçın P. Heterotopik ossifikasyon. Romatizma 2003; 18: 183-90.

2. Zinnuroğlu M, Kaymak Karataș G, Sepici V. Heterotopic ossification due to neuromuscular blocking agent in adult respiratory distress syndrome. A case report. Eur J Phys Rehabil Med 2008; 44: 81-5.

3. Sepici V. Heterotopik ossifikasyon. In: Beyazova M, Kutsal YG (eds). Fiziksel Tıp ve Rehabilitasyon. Ankara: Günes Kitabevi, 2000.

4. Tederko P, Limanowska H, Krasuski M, Kiwerski J. Problems of adaptation to wheelchair in early stage rehabilitation after spinal cord trauma. Ortop Traumatol Rehabil 2006; 8: 672-9.

5. Antonelli S, Sebastiani GD. Polyarticular heterotopic ossification complicating drug induced coma. Reumatismo 2002; 54: 59-61.

6. Reardon MJ, Tillou A, Mody DR, Reardon PR. Heterotopic calcification in abdominal wounds. Am J Surg 1997; 173: 145-7.

7. Jacobs JW, De Sonnaville PB, Hulsmans HM, van Rinsum AC, Bijlsma JW. Polyarticular heterotopic ossification complicating critical illness. Rheumatology (Oxford) 1999; 38: 1145-9.

8. Noel AA, Gloviczki P, Cherry KJ, Bower TC, Panneton JM, Mozes Gl, et al. Ruptured abdominal aortic aneurysms: the excessive mortality rate of conventional repair. J Vasc Surg 2001; 34: 41-6.

9. Goodman TA, Merkel PA, Perlmutter G, Doyle MK, Krane SM, Polisson RP. Heterotopic ossification in the setting of neuromuscular blockade. Arthritis Rheum 1997; 40: 1619-27.

10. Shimizu M, Nakayama M. Endometrial ossification in a postmenopausal woman. J Clin Pathol 1997; 50: 171-2.

11. Ansari MQ, Sachs IL, Max E, Alpert LC. Heterotopic bone formation in rectal carcinoma. Case report and literature review. Dig Dis Sci 1992; 37: 1624-9.

12. Cera G, Cardesi E. Diffuse pulmonary ossification and diabetes mellitus. An association not previously described. Pathologica 1996; 88(4): 313-6.

13. Nakagawa S, Tagami H. Metaplastic bone formation in the subcutaneous nodule of a patient with mixed connective tissue disease. Acta Derm Venereol 1997; 77: 64-5. 